\title{
EFFECT OF NUTRIENT SOLUTIONS AND DIFFERENT PLANTING BED ON SOME GROWTH CHARACTERISTICS OF STEVIA REBAUDIANA IN INOCULUM CONDITIONS WITH MYCORRHIZAL FUNGUS
}

\author{
SEYEDMOHAMMADI, N. S. ${ }^{1}$ - BARMAKI, M. ${ }^{1 *}$ - DAVARI, M. ${ }^{2}$ - HASHEMI MAJD, K. ${ }^{3}$ \\ ${ }^{I}$ Department of Agronomy and Plant Breeding, Faculty of Agriculture, University of \\ Mohaghegh Ardabili, Ardabil, Iran \\ ${ }^{2}$ Department of Plant Protection, Faculty of Agriculture, University of Mohaghegh Ardabili, \\ Ardabil, Iran \\ ${ }^{3}$ Department of Soil Science, Faculty of Agriculture, University of Mohaghegh Ardabili, \\ Ardabil, Iran \\ *Corresponding author \\ e-mail: barmakimorteza@gmail.com \\ (Received $4^{\text {th }}$ Jan 2019; accepted $12^{\text {th }}$ Feb 2019)
}

\begin{abstract}
Stevia is a perennial plant and is well-known for its high content of steviol glycoside in dryleaf matter that is responsible for providing the non-caloric value sweet taste. Stevia rebaudiana leaves contain diterpen glycosides, which are about 250 to 300 times more sweetened than sucrose, and their sweeteners are widely used today in the food and pharmaceutical industries. In order to study the effect of mycorrhiza fungi on some growth characteristics of the stevia herb in inoculum conditions with mycorrhizal fungus, a factorial experiment based on randomized complete block design with four replications was conducted in greenhouse of Mohaghegh Ardabili University in 2016. The first factor was Imma \& Angel and Novella nutrient solutions, the second factor was planting bed including leaf composts, vermicompost and biolan (peat \& perlite) and third factor Inoculation with mycorrhiza and control fungi showed that the highest fresh and dry weight of leaves and number of number of leaves to the Imma \& Angel nutrient solution in vermicompost planting bed under inoculation with mycorrhiza. The highest plant height was related to the Imma \& Angel nutrient solution in leaf composts planting bed was observed under inoculum with mycorrhiza and the highest chlorophyll content was observed for Novella nutrient solution in vermicompost planting bed under inoculation conditions with mycorrhiza.

Keywords: Stevia, biofertilizers, hydroponic, mycorrhiza
\end{abstract}

\section{Introduction}

Stevia rebaudiana Bertoni (Asteracea family) is a herbaceous, perennial and indigenous herbaceous plant in Paraguay and Brazil and its leaf is used as a calorie-free natural sweetener for diabetic patients and for the prevention of obesity (Garana et al., 2010). Stevia has high nutrient requirements, especially N, P and K, and the lack of these elements has a major constraint on the quantity and quality of biomass of this plant (Pramanik and Singh, 2003). A proposal to prevent the effects of chemical fertilizers on the plant, which may overwhelm the good properties of the plant, is to examine the impact of bio-fertilizers that are present in mycorrhizal fungi or bacteria on the growth of this plant. Growth stimulating microorganisms include mycorrhizal fungi and a group of bacteria, and the most important glomus mycorrhizal fungi can be mentioned (Cocking, 2003). In hydroponic system, all essential elements should be given as soluble salts to the plant. A proper nutritional solution is a solution that 
contains all the nutrients in certain concentrations, and the experts, based on the research components and the conditions of cultivation and plant species studied, have changed from standard solutions or different concentrations of it (Tabatabaei et al., 2006). Proper media, in addition to the desired physical, chemical and biological properties, should be accessible, sustainable and economically feasible (Davidson et al., 1998). The planting bed used in this qualification were listed (Table 1).

Table 1. Concentration of nutrient solution elements $(\mathrm{mg} / \mathrm{l})$

\begin{tabular}{c|c|c}
\hline Elements & Imma \& Angel (2006) & Novella et al. (2008) \\
\hline $\mathrm{KNO}_{3}$ & 40.4 & 505 \\
$\mathrm{Ca}\left(\mathrm{NO}_{3}\right)_{2}$ & 254.2 & 656 \\
$\mathrm{NH}_{4} \mathrm{NO}_{3}$ & 352 & 47 \\
$\mathrm{KH}_{2} \mathrm{PO}_{4}$ & 598.4 & 240 \\
$\mathrm{MgSO}_{4}$ & 96 & 180 \\
$\mathrm{Na}_{2} \mathrm{MoO}_{4}$ & 0.033 & $0 / 055$ \\
$\mathrm{H}_{3} \mathrm{BO}_{3}$ & 2.21 & 1.56 \\
$\mathrm{CuSO}_{4}$ & 0.481 & 0.912 \\
$\mathrm{ZnSO}_{4}$ & 0.645 & 1.07 \\
$\mathrm{MnSO}_{4}$ & 5.15 & 8.5 \\
$\mathrm{Fe}-\mathrm{EDDHA}$ & 13.25 & 4 \\
\hline
\end{tabular}

Vermicompost has substances such as plant growth hormones and enzymes that increase the microbial population of the soil and preserve the nutrients for longer periods without negative effects on the environment (Padmavathiamma et al., 2008). Perlite has a slight weight, is chemically neutral and has a high porosity and water holding capacity. Vermiculite also has a high cation exchange capacity and is chemically active (Malakouti et al., 2005). Perlites are often used alone or in combination with vermiculite 1: 1 volumes alone (Malakouti et al., 2008). This material provides suitable conditions for plant growth, such as ventilation, drainage and access to nutrients, especially in combination with other substrates (Martinez and Abad, 1992). Peat Moss is a degraded particle that is produced in humid and cold areas. The type of composition and its constituent varies in different types (Rafiei and Akbarzadeh, 2007).

Peat Moss is a plant material that breaks down slightly in mossy soils, as well as anaerobic conditions such as swamps and marshes, and has acidic $\mathrm{pH}$. The cation exchange capacity of this substance is very high and the EC has a low (about ds.m 0.5) (Samiei et al., 2004). Mycorrhizal fungi in direct ways such as improving plant nutrition by increasing the absorption of water and nutrients, in particular, low-mobility elements such as phosphorus (Smith and Read, 1997), as well as the production of hormones such as auxin, cytokinin and abscisic acid in stimulating plant growth (Awotoye et al., 2009) and indirectly, such as reduction of biological stresses of plant diseases (Calvet et al., 1995) and non-toxic (salinity, drought, heavy metals, etc.) increase growth and yield Plants are hosted (Raiesi and Ghollarata, 2006). Research has shown that bio-fertilizers significantly provide plant nutrients such as nitrogen, phosphorus and potassium, and The other side protects the plant against various environmental stresses and increases plant resistance under stress conditions (Smith and Read, 1997).

The purpose of this study was to investigate the effect of nutrient solutions and planting bed (Peat moss and Perlite, leaf compost and vermicompost) simultaneously on Glomus mosseae mycorrhiza inoculum on some growth characteristics of stevia herb. 


\section{Methods and materials}

In order to investigate the effect of Nutrient solutions and different planting bed on some growth characteristics of Stevia rebaudiana under inoculation with mycorrhizal fungus, a factorial design based on randomized complete block design with 4 replications in greenhouse of Mohaghegh Ardebili University in 2016 was conducted. The first factor was two levels: two different Nutrient solution solutions including Imma \& Angel and Novella et al. (Table 1), the second factor was planting bed including Peat Moss and Perlite (Biolan), Vermicompost and Leaf composts in three levels and the third factor were inoculated with mycorrhizal fungus from Glomus mosseae and control treatment at two levels. After planting seedlings in pots, they were fed continuously with drops in nutrient solutions. Height of plant with ruler, number of leaves with counting, vegetation rate with cost meter (chlorophyll meter) Konica Minolta 502 according to SPAD index, fresh and dry weight of leaf was measured by digital scale. The analysis of data variance was done using SAS 9.2 software and the mean values were compared at the probability level of $1 \%$ and $5 \%$ using LSD Test.

\section{Results and discussion}

\section{Leaf fresh weight}

The results of analysis of variance of trait weight of leaf in stevia were significantly affected by the treatments at $1 \%$ level (Table 2). The results of analysis of variance of interaction between Nutrient solution solutions, different planting bed and inoculation with mycorrhizal fungus showed a significant difference. Mean comparison showed that the Imma \& Angel solution in the planting bed of vermicompost under the conditions of mycorrhizal fungus $(666.8 \mathrm{~g})$ had the highest leaf fresh weight (Table 3).

Table 2. Analysis of variance of the effects of treatments on Leaf fresh weight, Leaf dry weight, Number of leaves, Plant height and Chlorophyll

\begin{tabular}{c|c|c|c|c|c|c}
\hline & \multicolumn{6}{|c}{ Mean squares } \\
\hline Source of variances & df & $\begin{array}{c}\text { Leaf fresh } \\
\text { weight }\end{array}$ & $\begin{array}{c}\text { Leaf dry } \\
\text { weight }\end{array}$ & $\begin{array}{c}\text { Number of } \\
\text { leaves }\end{array}$ & Plant height & Chlorophyll \\
\hline Repetition & 3 & $6341 / 66$ & $458 / 33$ & $631637 / 5$ & $712 / 423$ & $18 / 57$ \\
Nutrient solution & 1 & $88648 / 83^{* *}$ & $732 / 57^{* *}$ & $2643285 / 33^{* *}$ & $1656 / 75^{*}$ & $147 / 17^{*}$ \\
Planting bed & 2 & $124957 / 51^{* *}$ & $7237 / 26^{* *}$ & $7710277^{* *}$ & $347 / 078^{\mathrm{ns}}$ & $38 / 52^{\mathrm{ns}}$ \\
$\begin{array}{c}\text { Inoculation } \\
\text { Planting bed } \times \text { nutrient } \\
\text { solution }\end{array}$ & 1 & $46800 / 03^{* *}$ & $2215 / 17^{* *}$ & $99372^{* *}$ & $2976 / 75^{* *}$ & $0 / 574^{\mathrm{ns}}$ \\
$\begin{array}{c}\text { Nutrient } \\
\text { solution } \times \text { Inoculation }\end{array}$ & 1 & $79283 / 76^{* *}$ & $430 / 08^{* *}$ & $2033633 / 33^{* *}$ & $500 / 52^{\mathrm{ns}}$ & $30 / 16^{\mathrm{ns}}$ \\
$\begin{array}{c}\text { Planting bed } \times \text { Inoculation } \\
\text { Planting bed } \times \text { nutrient } \\
\text { solution } \times \text { Inoculation }\end{array}$ & 2 & $144228 / 91^{* *}$ & $9578 / 57^{* *}$ & $10889749^{* *}$ & $1773 / 109^{*}$ & $116 / 122^{*}$ \\
\hline Error & 2 & $11865 / 36^{* *}$ & $1929 / 62^{* *}$ & $4705210 / 33^{* *}$ & $602 / 036^{\mathrm{ns}}$ & $182 / 967^{* *}$ \\
\hline \begin{tabular}{c} 
\% CV \\
\hline
\end{tabular} & - & 14 & $197 / 6^{* *}$ & $640164 / 33^{* *}$ & $316 / 797^{\mathrm{ns}}$ & $31 / 48^{\mathrm{ns}}$ \\
\hline
\end{tabular}

**and * were significant at level of probability of $1 \%$ and $5 \%$ and without significant differences 
Table 3. Comparison of the average effect of different treatments on Leaf fresh weight, Leaf dry weight, Number of leaves, Plant height and Chlorophyll

\begin{tabular}{|c|c|c|c|c|c|c|c|}
\hline \multirow{2}{*}{\multicolumn{3}{|c|}{ Treatments }} & \multicolumn{5}{|c|}{ Mean } \\
\hline & & & \multirow{2}{*}{$\begin{array}{c}\begin{array}{c}\text { Leaf fresh } \\
\text { weight }\end{array} \\
145 b\end{array}$} & \multirow{2}{*}{$\begin{array}{c}\begin{array}{c}\text { Leaf dry } \\
\text { weight }\end{array} \\
46 / 8 \mathrm{c}\end{array}$} & \multirow{2}{*}{$\begin{array}{c}\begin{array}{c}\text { Number of } \\
\text { leaves }\end{array} \\
2332 b\end{array}$} & \multirow{2}{*}{\begin{tabular}{|c|} 
Plant height \\
99/75abcd
\end{tabular}} & \multirow{2}{*}{$\begin{array}{c}\text { Chlorophyll } \\
36 / 45 \mathrm{bc}\end{array}$} \\
\hline \multirow{6}{*}{ Novella } & Leaf composts & $\begin{array}{l}\text { Mycorrhiza } \\
\text { inoculation }\end{array}$ & & & & & \\
\hline & & Control & $81 / 5 \mathrm{de}$ & $18 / 2 \mathrm{~g}$ & $993 \mathrm{~h}$ & $65 / 63 d$ & 41/838ab \\
\hline & Vermicompost & $\begin{array}{l}\text { Mycorrhiza } \\
\text { inoculation }\end{array}$ & $142 / 5 b$ & $77 / 5 b$ & $2080 \mathrm{c}$ & $78 / 5$ de & $45 / 513 \mathrm{a}$ \\
\hline & & Control & $140 / 8 b$ & $38 / 6 \mathrm{de}$ & $1736 \mathrm{~d}$ & $102 / 5 \mathrm{abcd}$ & $37 / 2 b c$ \\
\hline & $\begin{array}{c}\text { Peat moss \& } \\
\text { Perlite }\end{array}$ & Mycorrhiza & $151 / 7 \mathrm{~b}$ & $39 / 7 \mathrm{de}$ & $1480 \mathrm{ef}$ & $109 / 63 a b c$ & 39/388ab \\
\hline & & Control & $84 / 7 \mathrm{de}$ & $26 / 1 \mathrm{f}$ & $687 \mathrm{i}$ & $91 / 88 \mathrm{bcde}$ & $38 / 213 b c$ \\
\hline \multirow{6}{*}{$\begin{array}{c}\text { Imma \& } \\
\text { Angel }\end{array}$} & Leaf composts & $\begin{array}{l}\text { Mycorrhiza } \\
\text { inoculation }\end{array}$ & $150 / 3 b$ & $43 / 6 \mathrm{~cd}$ & 1646de & $123 \mathrm{a}$ & $36 / 225 b c$ \\
\hline & & Control & $123 / 6 b c$ & $35 / 2 \mathrm{e}$ & 1060gh & $81 / 5$ cde & $41 / 538 \mathrm{ab}$ \\
\hline & Vermicompost & Mycorrhiza & $666 / 8 \mathrm{a}$ & $128 / 1 \mathrm{a}$ & $4653 a$ & $112 \mathrm{ab}$ & $31 / 4 \mathrm{~cd}$ \\
\hline & & Control & $105 / 1 \mathrm{~cd}$ & $27 / 18 f$ & $1012 \mathrm{~h}$ & $96 / 25 \mathrm{abcd}$ & 41/113ab \\
\hline & $\begin{array}{l}\text { Peat moss \& } \\
\text { Perlite }\end{array}$ & $\begin{array}{l}\text { Mycorrhiza } \\
\text { inoculation }\end{array}$ & $96 / 7$ cde & $26 f$ & $1270 f g$ & $107 / 5 \mathrm{abc}$ & $38 / 463 b$ \\
\hline & & Control & $65 / 2 \mathrm{e}$ & $18 / 3 \mathrm{~g}$ & $550 \mathrm{i}$ & 98/13abcd & $28 / 85 \mathrm{~d}$ \\
\hline
\end{tabular}

Similar letters to the averages in each column indicate no significant difference at the $5 \%$ level (LSD test)

\section{Leaf dry weight}

The results of this experiment showed that this trait was affected by different nutrient solutions, different planting bed and inoculation with mycorrhizal fungus at a one percent significance level (Table 2). The results of analysis of variance of interaction between Nutrient solution solutions, different planting bed and inoculation with mycorrhizal fungus showed a significant difference. Mean comparison showed that the Imma \& Angel nutrient solution in the planting bed of vermicompost had the highest leaf dry weight under inoculation with mycorrhizal fungus (128.1 g) (Table 3).

Research by Silveira et al. (2006) showed that the symbiosis of plants with mycorrhizal fungi improves plant growth characteristics, including the development of vegetative parts and the increase of fresh and dry weight of plant tissues. (Hawkesford et al., 2012) stated that phosphorus deficiency impairs plant growth and affects its various aspects of metabolism. Deficiency of phosphorus disrupts the transfer of water through the root, and because of the lack of adequate water for expansion of the cells, the leaves remain small and the growth of the air organs is prevented, thus, in the present experiment, Mycorrhiza fungus, with the availability of more phosphorus for the plant, increased the growth of the plant's airways. Also, vermicompost planting bed caused more vegetative growth because of the presence of more amounts of precipitated elements.

The trait of leaf number in Stevia plant was affected by the treatments at $1 \%$ level (Table 2). The results of analysis of variance of interaction between Nutrient solution solutions, different planting bed and inoculation with mycorrhizal fungus showed a significant difference. The mean comparison showed that the Imma \& Angel diet in the planting bed of vermicompost had the highest number of leaves in inoculation with mycorrhizal fungus (4653) (Table 3). The growth of Imma \& Angel, due to providing more suitable conditions for vegetative growth, resulted in more leaves. Vermicompost 
has a positive effect on the amount of photosynthesis and production of biomass of stevia, by increasing the water absorption capacity and the optimum access to highconsumption and low nutrient elements, resulting in more plant growth and increased leaf number. Also, according to Yousefi Shayade et al. (2015), the planting bed containing vermicompost increased the number of leaves in the stevia. (Bachman and Metzger, 2008) reported that adding vermicompost to soil increases leaf number, leaf area. The amount of photosynthesis in the French spring rose. Today it is known that direct mycorrhizal fungi increase plant growth by direct methods such as improving plant nutrition through absorption of nutrients, as well as increasing plant and inbound water absorption, such as decreasing biological stresses (Tahat and Sijam, 2012). The increase in the number of leaves in plants was reported by inoculation with mycorrhizal fungus in comparison with non-inoculated plants in tomato (Khalied and Elkhider, 1993) and Citrus tangering seedlings ( $\mathrm{Wu}$ and Xia, 2006). An increase in the number and level of leaf associated with mycorrhizal fungi has also been reported by Copetta et al. (2006) in Basil, which is consistent with the results of this experiment.

\section{Plant height}

The height of plant was affected by different nutrient solutions at 5\% level, and the highest number of leaves belonged to Imma \& Angel $(91.313 \mathrm{~cm})$. Inoculation with mycorrhizal fungus $(105.063 \mathrm{~cm})$ also showed a significant difference in the level of one percent (Table 2). The results of analysis of variance of interaction between different substrates of culture and inoculation with mycorrhizal fungi showed a significant difference at $1 \%$ level. The highest plant height was related to the culture of leaf soil culture under inoculation with mycorrhizal fungus with $111.375(\mathrm{~cm})$. The comparison of the mean showed that the Imma \& Angel nutrient solution in the soil planting bed under inoculum conditions with mycorrhizae $(123 \mathrm{~cm})$ had the highest plant height (Table 3). Utumi et al. (1999) conducted a stevia test The effect of nitrogen nutrient deficiency on the absorption of high-energy elements by the plant was that they said that the deficiency of this nutrient component would reduce the absorption of highenergy nutrients in this plant and decrease the plant's height. Studies by Sheelavanta (1993) showed that with increasing nitrogen fertilization, the length of safflower stem increased. Principally, the cause of increasing altitude due to the use of urea can be attributed to the effect of nitrogen escalation on vegetative growth and cell division in the plant, especially the stem, and more photosynthetic extraction is expected to be produced by the plant, which is a good condition Provides for elongation of the stem (Nourmohammadi et al., 2001). Saberhamishiegi et al. (2012) reported a study on the effects of nitrogen and potassium on the Stevia plant. The highest stem length (altitude) was observed in $60 \mathrm{~kg} / \mathrm{ha}$ treatment and the least nitrogen application was obtained. Due to the fact that the percentage of nitrogen in the Imma \& Angel sugars is higher, it can be attributed to the effect of nitrogen on the height of plants treated with this solution. According to the results, arbuscular mycorrhizal fungi had a positive effect on growth traits (plant height and branch number), which was consistent with the results of Piedra et al. (2005) and Soriano et al. (2009).

\section{Chlorophyll}

The results of analysis of variance of interaction between Nutrient solution solutions, different planting bed and inoculation with mycorrhizal fungus showed significant differences. Comparison of the mean showed that Novella nutrient solution in 
vermicompost was in inoculated with mycorrhizal fungus at 45.513 (Table 3). With the presence of nitrogen in the chlorophyll components, it can be expected that with increasing nitrogen levels, it will have a significant effect on the chlorophyll content of leaves. The presence of chlorophyll as a source of light absorption and the synthesis of essential elements for the growth of plants associated with this element is critical (Saberhamishi et al., 2014). Sedeghi Moghadam and Mirzaie (2008) reported that adding vermicompost to soil causes nitrogen absorption by the roots, increasing vegetative growth and producing more leaves, which in turn increases the level of absorption of light, the level of photosynthesis, the creation and b, a hydrocarbon substances in leaves and total chlorophyll content increase.

Increasing chlorophyll content of leaves due to mycorrhizal coexistence can be due to increased phosphorus absorption from the soil by these fungi. Demir (2004) showed that mycorrhizal coexistence increases the concentration of chlorophyll in pepper plant leaves. According to the results of Hoseini et al. (2015), mycorrhizal inoculated plants contain more vegetation than control. Also, Tang et al. (2009) observed in their study of maize that insemination with the G.mossea mushroom improved the chlorophyll synthesis in the plant and increased the photosynthesis of the plant. They attributed this to increasing nitrogen absorption by mycorrhizal plants.

\section{REFERENCES}

[1] Awotoye, O. O., Adewole, M. B., Salami, A. O., Ohiembor, M. O. (2009): Arbuscular mycorrhiza contribution to the growth performance and heavy metal uptake of Helianthusannuus LINN inpot culture. - African Journal of environmental Scince and Technology 3: 157-163.

[2] Bachman, C. R., Metzger, J. D. (2008): Growth of bedding plants in commercial potting substrate amended with vermicompost. - Bioresour. Technol. 99: 3155-3161.

[3] Calvet, C., Pinochet, J., Hernandez-Dorrego, A., Estan, V., Camprubi, A. (2001): Field microplot performance of the peach-almond hybrid GF-677 after inoculation with arbuscular mycorrhizal fungi in a replant soil infested with root-knot nematodes. Mycorrhiza 10: 295-300.

[4] Cocking, E. C. (2003): Endophytic colonization of plant roots by nitrogen fixing bacteria. - Plant Soil 252: 169-175.

[5] Copetta, A., Lingua, G., Bert, G. (2006): Effect of three AM fungi on growth, distribution of glandular facilitation of plat phosphate acquisition by arbuscular mycorrhiza from enriched soil patches roots and hyphae exploiting the same soil volume. - New Phytol. 133(3): 453-460.

[6] Davidson, H., Mecklenburg, R., Peatrson, C. (1998): Nursery management: administration and culture. - Inc. New Jersey: 173.

[7] Demir, S. (2004): Influence of arbuscular mycorrhiza on some physiological growth parameters of pepper. - Turk. J. Biol. 28: 85-90.

[8] Gardana, C., Scaglianti, M., Simonetti, P. (2010): Evaluation of steviol and its glycosides in Stevia rebaudiana leaves and commercial sweetener by ultra-high-performance liquid chromatography-mass spectrometry. - J. Chromatography A 1217(9): 1463-1470.

[9] Hawkesford, M., Horst, W., Kichey, T., Lambers, H., Schjoerring, J., Skrumsager Moller, I., White, P. (2012): Functions of macronutrients. - In: Marschner, P. (ed.) Marschner's Mineral Nutrition of Higher Plants. Oxford, UK. pp. 135-190.

[10] Hoseini, R. Z., Goltapeh, E. M., Kalatejari, S., Dehghani Mashkani, M. R. (2015): Effect of vermicompost and inoculation of fungi on growth characteristics and steviosidicity of leafy herb (Stevia rebaudiana Betroni). - Journal of Medicinal Plants 4(56): 179-188. 
[11] Imma, F., Angel, M. (2006): Potato minituber production using aeroponics: Effect of plant density and harvesting intervals. - American Journal of Potato Research 83: 47-53.

[12] Khalied, A. S., Elkhider, R. A. (1993): Vesicular-arbuscular mycorrhizas and soil salinity. - Mycorrhiza 4: 45-57.

[13] Malakouti, M. J., Tabatabaei, J., Kafi, M. (2005): New methods for timely supply of nutrients in plants. - Senate Press, Tehran: 388.

[14] Martinez, P. F., Abad, M. (1992): Soilless culture of tomato in different mineral substrates. - Acta Hort. 323: 251-259.

[15] Nourmohammadi, G., Siyadat, S., Kashani, A. (2001): Agriculture (Vol. I-Grains). Third edition, Shahid Chamran University Press. p. 446.

[16] Novella, M. B., Andriolo, J. L., Bisognin, D. A., Melo, C. C., Guerra, B. M. (2008). Concentration of nutrient solution in the hydroponic production of potato minitubers. Ciencia Rural, Santa Maria 38(6): 1529-1533.

[17] Padmavathiamma, P. K., Li, L. Y., Kumari, U. R. (2008): An experimental study of vermi-biowaste composting for agricultural soil improvement. - Bio resource Technology 99: 1672-1681.

[18] Paul, L. C., Metzger, J. D. (2005): Impact of vermicompost on vegetable transplant quality. - Hort. Sci. 40(7): 2020-2023.

[19] Piedra, A., Sorianomartin, M., Sorriano, A., Fernandez, G. (2005): Influence of Arbuscular mycorrhizas on the growth rate of mist propagated olive plantlets. - Spanish journal of agricultural research 3(1): 98-105.

[20] Pramanik, K., Singh, R. K. (2003): Effect of levels and mode of phosphorus application with and without biofertilizer on yield and nutrient uptake by chickpea (Cicer arietinum). - Ann. Agric. Res. New Sciences 24(4): 768.

[21] Raiesi, F., Ghollarata, M. (2006): Interactions between phosphorus availability and an AM fungus (Glomus intraradices) and their effects on soil microbial respiration, biomass and enzyme activities in a calcareous soil. - Pedobiologia 50: 413-425.

[22] Saberhameshagi, F., Torang, A. S. R., Mobalege, M., Dehpour, A. S. (2014): Effect of different levels of nitrogen and potassium on morphological and chemical characteristics of the Stevia plant. - The findings of modern agriculture 7(2): 128-135.

[23] Sedghi Moghadam, M., Mirzaei, M. (2008): The Effect of Urban Waste Compost on the Quantitative and Qualitative Characteristics of Pumpkin (Cucurbita Moschata Duch. Ex Poir.). - Third National Recycling Congress and the Use of Renewable Organic Resources in Agriculture, Islamic Azad University, Khorasgan Branch, Isfahan, pp. 1-7.

[24] Sheelavanta, M. N. (1993): Response of safflower (Carthemus tinctorius L.) varieties tonitrogen levels under rainfed condition. - M. Sc. (Agri.) Thesis, University of Agricultural Sciences Bangalore.

[25] Silveira, S. A., Lorscheiter, R., Barrow, I. B. I., Schwarz, S. F., Souza, P. W. D. (2006): Mentha piperata as a multiplyin host of AM fungi. - HYPERLINK "http://cassi.cas.org/publication.jsp? P=eCQtRPJo9AQyz133K_ll3zLPXfcrWXfJIIAZaSqDc1O_ar-dDnYnTLPXfcr-WXfimSBIkq8XcUjhmkOWtYxmzLPXfcrWXfJNYTTBrP9cniVlhZUZVmng" Revista Brasileira. Pl. Med 8: 91-7.

[26] Smith, S. E., Read, D. J. (1997): Mycorrhizal Symbiosis. - 2nd ed. Academic Press, San Diego, CA.

[27] Soriano, A., Martin, M., Piedra, A., Azcon, R. (2009): Arbuscular micorrhizal fungi increased growth, nutrient uptake and tolerance to salinity in olive trees under nursery conditions. - Journal of Plant Physiology 166: 1350-1359.

[28] Tabatabaei, J., Nazariju, R., Rostami, F., Azarmi, F., Pahnaei, S. (2006): Evaluation of nitrate concentration of leafy vegetables, germs and mites in Tabriz city. - Fourth Congress of Iranian Horticultural Sciences, Ferdowsi University of Mashhad.

[29] Tahat, M. M., Sijam, K. (2012): Mycorrhizal fungi and abiotic environmental conditions relationship. - Res. J. Environ. Sci. 6: 125-133. 


$$
\text { - } 5648 \text { - }
$$

[30] Tang, M., Chen, H., Huang, J. C., Tian, Z. Q. (2009): Arbuscular mycorrhiza fungi effects on the growth and physiology of (Zea mays L.) seedlings under diesel stress. Soil Biology Biochemistry 41: 936-940.

[31] Utumi, M. M., Monnerat, P. H., Pereira, P. R. G., Fontes, P. C. R., Godinho, V. D. P. C. (1999): Macronutrient deficiencies in Stevia: Visual symptoms and effects on growth, chemical composition, and stevioside production. - Pesquisa Agropecuária Brasileira 34(6): 1038-1043.

[32] Wu, Q. S., Xia, R. X. (2006): Arbuscular mycorrhizal fungi influence growth, osmotic adjustment and photosynthesis of citrus under well-watered and water stress conditions. J. Plant Physiol. 163: 417-425.

[33] Yousefi Shayadeh, S. M., Chalavi, V., Zangi, S. (2015). Effect of different levels of vermicompost and duration of luminosity in greenhouse production of medicinal plant. Science and technology of greenhouse crops 21(6): 31-38. 